\title{
Efficient Synthetic Technique, PASS Predication, and ADMET Studies of Acylated $n$-Octyl Glucopyranosides
}

\author{
Mohammad Ali, Md. Hasanul Karim, and Mohammed Mahbubul Matin* \\ Bioorganic and Medicinal Chemistry Laboratory, Department of Chemistry, Faculty of \\ Science, University of Chittagong, Chattogram, 4331, Bangladesh
}

\begin{abstract}
Direct dimolar pentanoylation of octyl $\beta$-D-glucopyranoside $(O B G)$ in pyridine-chloroform solvent system furnished the corresponding 3,6-di-O-pentanoate in improved yield. The pentanoate was further converted into three 2,4-di-O-acyl esters to get novel octyl glucopyranosides. To explore the medicinal probability of OBG-based esters, all the synthesized compounds were subjected to in silico PASS (prediction of activity spectra for substances) predication and ADMET (absorption, distribution, metabolism, excretion, and toxicity) studies. Both the studies indicated that OBG derived carbohydrate fatty acid (CFA) esters are a potential alternative for multidrug-resistant (MDR) pathogens, especially for fungal infections.
\end{abstract}

Keywords: n-Octyl $\beta$-D-glucopyranoside (OBG), Carbohydrate Fatty Acid (CFA) Esters (SEs), PASS Predication, ADMET, SwissADME.

\section{Introduction}

The numerous biological properties of carbohydrate derivatives have garnered special attention from researchers [1-2]. Among them, carbohydrate fatty acid (CFA) esters are important due to them being amphiphilic, non-toxic, biodegradable, non-irritating and environment-friendly [3-6]. In addition to their uses as detergent and cosmetic products, some CFA esters are used in pharmaceutical industries considering their suitable insecticidal and antimicrobial activities [7-9]. Recently, it was observed that sugar ester part(s) of uridine (1, Figure 1) is more potent against SARS-CoV-2 main protease (Mpro; 7BQY) than the traditional hydroxychloroquine (HCQ, 2) drug [10]. Therefore, the CFA esters have always been an important component(s) of drugs, and their design and synthesis play an important role in the diagnosis, prevention and treatment of diseases.<smiles>[R]C1[C@H](COC(=O)c2ccc(C(C)(C)C)cc2)O[C@@H](n2ccc(=O)[nH]c2=O)[C@@H]1[R]</smiles>

1: $\mathrm{R}=$ acyl groups<smiles>CCC(CCCO)CCCC(C)Nc1ccnc2cc(Cl)ccc12</smiles>

Figure 1. Structure of compound $\mathbf{1}$ and $\mathbf{2}$.

\footnotetext{
* Corresponding author. Tel.: +880-1716-839689; fax: +880-31-2606014; https://orcid.org/0000-0003-4965-2280

E-mail address: mahbubchem@cu.ac.bd; mmmatin2004@yahoo.co.in
}

Manuscript History:

Received 7 December, 2020, Revised 3 January, 2021, Accepted 6 January, 2021, Published 30 April, 2021

e-ISSN: $2289-7771$

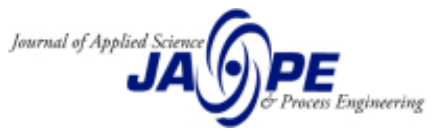


CFA esters are also used as significant intermediates in the syntheses of various natural products due to the presence of multifunctional groups, [11-13] in addition to their extensive use for the design and development of new drugs [14-15]. They can be synthesized by an esterification reaction between sugars (sugar alcohols) and non-polar fatty acids or acyl halides in basic solvent(s) [16]. Also, these can be achieved by using catalytic and enzymatic methods. However, industrial sugar esters are currently being manufactured by chemical syntheses. The major challenges with CFA ester syntheses are: (i) the presence of several $2^{\circ}$ hydroxyl groups of almost similar reactivity, mostly affecting functionalization (esterification) step which form a mixture of mono-, di-, and polyesters [16], and (ii) the many variations of carbohydrate structures. The separation of the different esterification mixtures into individual sugar esters is practically challenging and imposes high process cost. Hence, several methods have been attempted and reported in the last couple of decades for selective esterification (acylation) [17-26]. There are advantages and shortcomings in all the methods and/or strategies. Some of the shortcomings reported were the complex processes involving multiple steps, and they were tedious, expensive, had low selectivity and gave extremely low yield [27-28]. Hence, in most cases, a direct acylation technique maintaining proper reaction conditions is preferred for the monosaccharide based CFA ester synthesis to increase the final yield(s) [29-32].

From the structure-activity relationship (SAR) of several CFA esters, it was found that several acylated methyl 4,6-O-benzylidene- $\alpha$-D-glucopyranosides 3a,b (Figure 2) exhibited promising antimicrobial activities especially antifungal activities at a very low concentration [33-34]. The activities generally increased with the increase of hydrophobic character, and also depend on the nature and length of the lipophilic side chain(s) $[3-4,16]$.

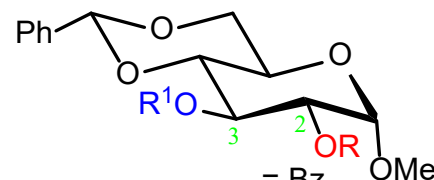

3a: $\mathrm{R}=\mathrm{R}^{1}=\mathrm{Bz}$

3a: $R=R=T s ; R^{1}=H$

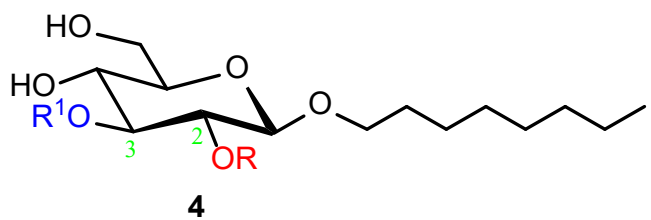

4

Figure 2. Structure of glucopyranosides 3 and 4.

Thus, the nature and mode of action of the CFA compounds are still open for future scientific and applied studies although these esters have been known for many years with a variety of applications. Octyl $\beta$-D-glucopyranoside (OBG, 4), a bio-surfactant, was found to be nontoxic and to inhibit carbohydrate hydrolyzing enzymes (like $\alpha$-amylase). In this context, and our continuous effort in this field [35-37] led us to design and synthesize some esters of octyl $\beta$-D-glucopyranoside (OBG, 4) for in silico biological spectrum and drug-likeness studies.

\section{Materials and methods}

\subsection{Instrumentation and general methods}

The melting point (mp) was determined on an electro-thermal melting point apparatus (England) and was uncorrected. Evaporations were carried out under diminished pressure using a Buchi rotary evaporator (R-100, Switzerland) with a bath temperature of below $40{ }^{\circ} \mathrm{C}$. Thin-layer chromatography (TLC) was performed on Kieselgel $\mathrm{GF}_{254}$ and the spots were detected by spraying the plates with $1 \%$ $\mathrm{H}_{2} \mathrm{SO}_{4}$ and heating it at $150-200{ }^{\circ} \mathrm{C}$ till a blackish colouration appeared. For work-up, a few pieces of ice were added to the reaction mixture to decompose the excess acyl halide and extracted with dichloromethane (DCM, $5 \times 3 \mathrm{~mL})$. The DCM layer was washed successively with $5 \%$ hydrochloric acid, saturated aqueous sodium hydrogen carbonate solution and brine. The DCM layer was dried and 
concentrated under reduced pressure. The residue obtained on column chromatography gave the corresponding pure compound(s). Column chromatography (CC) was performed with silica gel $\mathrm{G}_{60}$. The solvent system employed for the TLC analyses was $n$-hexane/ethyl acetate (EA) in different ratios. FT-IR spectra were recorded on an FT-IR spectrophotometer (Shimadzu, IR Prestige-21) in the $\mathrm{KBr}$ disc. ${ }^{1} \mathrm{H}$ (400 MHz, Bruker DPX-400 spectrometer, Switzerland) and ${ }^{13} \mathrm{C}(100 \mathrm{MHz}) \mathrm{NMR}$ spectra were recorded in $\mathrm{CDCl}_{3}$ solution using tunable multinuclear probe at Wazed Miah Science Research Centre (WMSRC), Jahangirnagar University, Bangladesh Chemical shifts were reported in $\delta$ scale (ppm) with reference to TMS (tetramethylsilane) as an internal standard and coupling constant $(J)$ values are shown in $\mathrm{Hz}$.

\subsection{Synthesis}

\subsubsection{Octyl 3,6-di- $O$-pentanoyl- $\beta$-D-glucopyranoside (5)}

A mixture of octyl $\beta$-D-glucopyranoside $(4,500 \mathrm{mg}, 1.71 \mathrm{mmol})$ in pyridine $(2 \mathrm{~mL})$ and chloroform $(2 \mathrm{~mL})$ was cooled to $10{ }^{\circ} \mathrm{C}$ whereupon pentanoyl chloride $(0.434 \mathrm{~g}, 3.59 \mathrm{mmol})$ was added to this mixture slowly. The mixture was warmed to $30^{\circ} \mathrm{C}$ and stirred for $10 \mathrm{~h}$ when TLC ( $n$ hexane/EA, 1/2, v/v) indicated the formation of one faster-moving major product. Work-up as mentioned in the previous section 2.1 , followed by chromatography gave the 3,6-di- $O$-pentanoate 5 (528 $\mathrm{mg}, 67 \%$ ) as a clear solid, $\mathrm{mp} 62-65^{\circ} \mathrm{C}$ [3].

$R_{\mathrm{f}}=0.48(n$-hexane/EA $=2 / 1)$; FT-IR $(\mathrm{KBr}): \vee 3250-3540(\mathrm{OH}), 1741,1733 \mathrm{~cm}^{-1}(\mathrm{CO}) ;{ }^{1} \mathrm{H}$ NMR (400 MHz, $\mathrm{CDCl}_{3}$ ): $\delta_{\mathrm{H}} 5.07$ (t, $\left.1 \mathrm{H}, J=9.6 \mathrm{~Hz}, \mathrm{H}-3\right), 4.48$ (dd, $1 \mathrm{H}, J=12.1$ and $\left.4.5 \mathrm{~Hz}, \mathrm{H}-6 \mathrm{a}\right)$, $4.42(\mathrm{dd}, 1 \mathrm{H}, J=2.0 \mathrm{~Hz}, \mathrm{H}-6 \mathrm{~b}), 4.34(\mathrm{~d}, 1 \mathrm{H}, J=8.2 \mathrm{~Hz}, \mathrm{H}-1), 3.83-3.93$ [m, 2H, H-2 and $\mathrm{CH}_{3}\left(\mathrm{CH}_{2}\right)_{6} \mathrm{CH}_{\mathrm{A}} \mathrm{H}_{\mathrm{B}} \mathrm{O}$ ], 3.46-3.59 [m, 3H, H-4, H-5 and $\mathrm{CH}_{3}\left(\mathrm{CH}_{2}\right)_{6} \mathrm{CH}_{\mathrm{A}} H_{\mathrm{B}} \mathrm{O}$ ], 2.46 [t, $2 \mathrm{H}, J=7.7 \mathrm{~Hz}$, $\left.\mathrm{CH}_{3}\left(\mathrm{CH}_{2}\right)_{2} \mathrm{CH}_{2} \mathrm{CO}\right], 2.38 \quad\left[\mathrm{t}, 2 \mathrm{H}, \quad J=7.6 \mathrm{~Hz}, \mathrm{CH}_{3}\left(\mathrm{CH}_{2}\right)_{2} \mathrm{CH}_{2} \mathrm{CO}\right], \quad 1.55-1.70 \quad[\mathrm{~m}, 6 \mathrm{H}$, $\mathrm{CH}_{3}\left(\mathrm{CH}_{2}\right)_{5} \mathrm{CH}_{2} \mathrm{CH}_{2} \mathrm{O}$ and $2 \times \mathrm{CH}_{3} \mathrm{CH}_{2} \mathrm{CH}_{2} \mathrm{CH}_{2} \mathrm{CO}$ ], 1.31-1.44 [m, $14 \mathrm{H}, \mathrm{CH}_{3}\left(\mathrm{CH}_{2}\right)_{5} \mathrm{CH}_{2} \mathrm{CH}_{2} \mathrm{O}$ and $2 \times \mathrm{CH}_{3} \mathrm{CH}_{2}\left(\mathrm{CH}_{2}\right)_{2} \mathrm{CO}$ ], 1.21-1.28 (br s, $\left.2 \mathrm{H}, 2 \times \mathrm{OH}\right), 0.95$ [t, $6 \mathrm{H}, J=7.6 \mathrm{~Hz}, 2 \times \mathrm{CH}_{3}\left(\mathrm{CH}_{2}\right)_{3} \mathrm{CO}$ ], 0.89 [t, $\left.3 \mathrm{H}, J=7.2 \mathrm{~Hz}, \mathrm{CH}_{3}\left(\mathrm{CH}_{2}\right)_{7} \mathrm{O}\right] ;{ }^{13} \mathrm{C}$ NMR $\left(100 \mathrm{MHz}, \mathrm{CDCl}_{3}\right): \delta_{\mathrm{C}} 174.4,174.2(\mathrm{CO}), 101.0(\mathrm{C}-1), 74.3$ (C-3), 74.2 (C-5), 71.1 (C-2), $70.4 \quad\left[\mathrm{CH}_{3}\left(\mathrm{CH}_{2}\right)_{6} \mathrm{CH}_{2} \mathrm{O}\right), 69.4$ (C-4), 63.0 (C-6), 34.1, 33.9 $\left[2 \times \mathrm{CH}_{3}\left(\mathrm{CH}_{2}\right)_{2} \mathrm{CH}_{2} \mathrm{CO}\right], 31.8,29.6,29.3,29.2,27.0,26.9,25.9,22.6,22.2,22.1\left[\mathrm{CH}_{3}\left(\mathrm{CH}_{2}\right)_{6} \mathrm{CH}_{2} \mathrm{O}\right.$ and $\left.2 \times \mathrm{CH}_{3}\left(\mathrm{CH}_{2}\right)_{2} \mathrm{CH}_{2} \mathrm{CO}\right], 14.0\left[\mathrm{CH}_{3}\left(\mathrm{CH}_{2}\right)_{7} \mathrm{O}\right], 13.6,13.5\left[2 \times \mathrm{CH}_{3}\left(\mathrm{CH}_{2}\right)_{3} \mathrm{CO}\right]$.

\subsubsection{Octyl 2,4-di- $O$-mesyl-3,6-di- $O$-pentanoyl- $\beta$-D-glucopyranoside (6)}

Mesylation of diol 5 (50 $\mathrm{mg}, 0.109 \mathrm{mmol})$ in anhydrous pyridine followed by workup and CC furnished the title compound $\mathbf{6}(60 \mathrm{mg}, 89 \%)$ as an oil.

$R_{\mathrm{f}}=0.48(n$-hexane/EA $=4 / 1)$; FT-IR $(\mathrm{KBr}): v 1748,1738(\mathrm{CO}), 1365,1362 \mathrm{~cm}^{-1}\left(\mathrm{SO}_{2}\right) ;{ }^{1} \mathrm{H}$ NMR (400 MHz, CDCl $)$ ): $\delta_{\mathrm{H}} 5.25(\mathrm{t}, 1 \mathrm{H}, J=9.8 \mathrm{~Hz}, \mathrm{H}-3), 5.10$ (t, $\left.1 \mathrm{H}, J=9.6 \mathrm{~Hz}, \mathrm{H}-4\right), 4.99$ (dd, $1 \mathrm{H}$, $J=9.6 \mathrm{~Hz}, \mathrm{H}-2), 4.47$ (d, $1 \mathrm{H}, J=8.2 \mathrm{~Hz}, \mathrm{H}-1), 4.23$ (dd, $1 \mathrm{H}, J=12.2$ and $4.8 \mathrm{~Hz}, \mathrm{H}-6 \mathrm{a}), 4.43$ (dd, $1 \mathrm{H}, J=2.4 \mathrm{~Hz}, \mathrm{H}-6 \mathrm{~b}), 3.89$ [dt, $1 \mathrm{H}, J=9.5$ and $6.4 \mathrm{~Hz}, \mathrm{CH}_{3}\left(\mathrm{CH}_{2}\right)_{6} \mathrm{CH}_{\mathrm{A}} \mathrm{H}_{\mathrm{B}} \mathrm{O}$ ], 3.67-3.74 (m, $\left.1 \mathrm{H}, \mathrm{H}-5\right)$, $3.47\left[\mathrm{dt}, 1 \mathrm{H}, J=9.5\right.$ and $6.9 \mathrm{~Hz}, \mathrm{CH}_{3}\left(\mathrm{CH}_{2}\right) 6 \mathrm{CH}_{\mathrm{A}} H_{\mathrm{B}} \mathrm{O}$ ], $3.29\left(\mathrm{~s}, 3 \mathrm{H}, \mathrm{SO}_{2} \mathrm{CH}_{3}\right), 3.15\left(\mathrm{~s}, 3 \mathrm{H}, \mathrm{SO}_{2} \mathrm{CH}_{3}\right)$, $2.36\left[\mathrm{t}, 2 \mathrm{H}, J=7.6 \mathrm{~Hz}, \mathrm{CH}_{3}\left(\mathrm{CH}_{2}\right)_{2} \mathrm{CH}_{2} \mathrm{CO}\right.$ ], 2.27 [t, $2 \mathrm{H}, J=7.4 \mathrm{~Hz}, \mathrm{CH}_{3}\left(\mathrm{CH}_{2}\right)_{2} \mathrm{CH}_{2} \mathrm{CO}$ ], 1.51-1.68 [m, $6 \mathrm{H}, \mathrm{CH}_{3}\left(\mathrm{CH}_{2}\right)_{5} \mathrm{CH}_{2} \mathrm{CH}_{2} \mathrm{O}$ and $2 \times \mathrm{CH}_{3} \mathrm{CH}_{2} \mathrm{CH}_{2} \mathrm{CH}_{2} \mathrm{CO}$ ], $1.27-1.42$ [m, $14 \mathrm{H}, \mathrm{CH}_{3}\left(\mathrm{CH}_{2}\right)_{5} \mathrm{CH}_{2} \mathrm{CH}_{2} \mathrm{O}$ and $\left.2 \times \mathrm{CH}_{3} \mathrm{CH}_{2}\left(\mathrm{CH}_{2}\right)_{2} \mathrm{CO}\right], 0.94 \quad\left[\mathrm{t}, 3 \mathrm{H}, J=7.6 \mathrm{~Hz}, \mathrm{CH}_{3}\left(\mathrm{CH}_{2}\right)_{3} \mathrm{CO}\right], 0.91 \quad[\mathrm{t}, 3 \mathrm{H}, J=7.6 \mathrm{~Hz}$, $\left.\mathrm{CH}_{3}\left(\mathrm{CH}_{2}\right)_{3} \mathrm{CO}\right], 0.88\left[\mathrm{t}, 3 \mathrm{H}, J=7.0 \mathrm{~Hz}, \mathrm{CH}_{3}\left(\mathrm{CH}_{2}\right)_{7} \mathrm{O}\right]$.

\subsubsection{Octyl 2,4-di- $O$-hexanoyl-3,6-di- $O$-pentanoyl- $\beta$-D-glucopyranoside (7)}

Diol 5 (50 mg, $0.109 \mathrm{mmol})$ on treatment with hexanoyl chloride $(32 \mathrm{mg}, 0.253 \mathrm{mmol})$ in dry pyridine $(1 \mathrm{~mL})$ for $12 \mathrm{~h}$ and $\mathrm{CC}$ purification gave compound $7(66 \mathrm{mg})$ as a thick syrup in $92 \%$. 
$R_{\mathrm{f}}=0.52(n$-hexane/EA $=4 / 1)$; FT-IR $(\mathrm{KBr}): v 1755,1749,1742,1738 \mathrm{~cm}^{-1}(\mathrm{CO}) ;{ }^{1} \mathrm{H}$ NMR $\left(400 \mathrm{MHz}, \mathrm{CDCl}_{3}\right): \delta_{\mathrm{H}} 5.21(\mathrm{t}, 1 \mathrm{H}, J=9.6 \mathrm{~Hz}, \mathrm{H}-3), 5.04(\mathrm{t}, 1 \mathrm{H}, J=9.6 \mathrm{~Hz}, \mathrm{H}-4), 5.02$ (dd, $1 \mathrm{H}, J=$ $9.6 \mathrm{~Hz}, \mathrm{H}-2), 4.45$ (d, $1 \mathrm{H}, J=8.0 \mathrm{~Hz}, \mathrm{H}-1), 4.22(\mathrm{dd}, 1 \mathrm{H}, J=12.2$ and $4.6 \mathrm{~Hz}, \mathrm{H}-6 \mathrm{a}), 4.13$ (dd, $1 \mathrm{H}, J$ $=12.2$ and $2.0 \mathrm{~Hz}, \mathrm{H}-6 \mathrm{~b}), 3.85$ [dt, $1 \mathrm{H}, J=9.6$ and $6.4 \mathrm{~Hz}, \mathrm{CH}_{3}\left(\mathrm{CH}_{2}\right)_{6} \mathrm{CH}_{\mathrm{A}} \mathrm{H}_{\mathrm{B}} \mathrm{O}$ ], 3.66-3.72 (m, $1 \mathrm{H}, \mathrm{H}-$ 5), 3.46 [dt, $1 \mathrm{H}, J=9.6$ and $\left.6.8 \mathrm{~Hz}, \mathrm{CH}_{3}\left(\mathrm{CH}_{2}\right)_{6} \mathrm{CH}_{\mathrm{A}} H_{\mathrm{B}} \mathrm{O}\right], 2.24-2.39\left[\mathrm{~m}, 8 \mathrm{H}, 2 \times \mathrm{CH}_{3}\left(\mathrm{CH}_{2}\right)_{2} \mathrm{CH}_{2} \mathrm{CO}\right.$ and $\left.2 \times \mathrm{CH}_{3}\left(\mathrm{CH}_{2}\right)_{3} \mathrm{CH}_{2} \mathrm{CO}\right], \quad 1.48-1.65 \quad\left[\mathrm{~m}, \quad 10 \mathrm{H}, \quad \mathrm{CH}_{3}\left(\mathrm{CH}_{2}\right)_{5} \mathrm{CH}_{2} \mathrm{CH}_{2} \mathrm{O}, \quad 2 \times \mathrm{CH}_{3} \mathrm{CH}_{2} \mathrm{CH}_{2} \mathrm{CH}_{2} \mathrm{CO}\right.$ and $2 \times \mathrm{CH}_{3}\left(\mathrm{CH}_{2}\right)_{2} \mathrm{CH}_{2} \mathrm{CH}_{2} \mathrm{CO}$ ], 1.20-1.35 [br m, 22H, $\mathrm{CH}_{3}\left(\mathrm{CH}_{2}\right)_{5}\left(\mathrm{CH}_{2}\right) 2 \mathrm{O}, 2 \times \mathrm{CH}_{3} \mathrm{CH}_{2}\left(\mathrm{CH}_{2}\right)_{2} \mathrm{CO}$ and $2 \times \mathrm{CH}_{3}\left(\mathrm{CH}_{2}\right)_{2}\left(\mathrm{CH}_{2}\right)_{2} \mathrm{CO}$ ], 0.88-0.95 [m, 15H, $\mathrm{CH}_{3}\left(\mathrm{CH}_{2}\right)_{7} \mathrm{O}, 2 \times \mathrm{CH}_{3}\left(\mathrm{CH}_{2}\right)_{3} \mathrm{CO}$ and $\left.2 \times \mathrm{CH}_{3}\left(\mathrm{CH}_{2}\right)_{4} \mathrm{CO}\right]$.

\subsubsection{Octyl 2,4-di-O-octanoyl-3,6-di- $O$-pentanoyl- $\beta$-D-glucopyranoside (8)}

Reaction of the diol 5 (50 mg, $0.109 \mathrm{mmol})$ and octanoyl chloride (39 $\mathrm{mg}, 0.24 \mathrm{mmol}$ ) followed by work-up and CC gave compound $\mathbf{8}(67 \mathrm{mg}, 87 \%)$ as a semi-solid which resisted crystallization.

$R_{\mathrm{f}}=0.56\left(n\right.$-hexane/EA = 4/1); FT-IR (KBr): $v 1754(2), 1742,1738 \mathrm{~cm}^{-1}(\mathrm{CO}) ;{ }^{1} \mathrm{H}$ NMR $(400$ $\left.\mathrm{MHz}, \mathrm{CDCl}_{3}\right): \delta_{\mathrm{H}} 5.19(\mathrm{t}, 1 \mathrm{H}, J=9.8 \mathrm{~Hz}, \mathrm{H}-3), 5.05(\mathrm{t}, 1 \mathrm{H}, J=9.8 \mathrm{~Hz}, \mathrm{H}-4), 5.00$ (dd, $1 \mathrm{H}, J=9.6 \mathrm{~Hz}$, $\mathrm{H}-2), 4.48(\mathrm{~d}, 1 \mathrm{H}, J=8.2 \mathrm{~Hz}, \mathrm{H}-1), 4.20(\mathrm{dd}, 1 \mathrm{H}, J=12.0$ and $4.8 \mathrm{~Hz}, \mathrm{H}-6 \mathrm{a}), 4.12(\mathrm{dd}, 1 \mathrm{H}, J=12.0$ and $2.0 \mathrm{~Hz}, \mathrm{H}-6 \mathrm{~b}), 3.85$ [dt, $1 \mathrm{H}, J=9.6$ and $6.4 \mathrm{~Hz}, \mathrm{CH}_{3}\left(\mathrm{CH}_{2}\right)_{6} \mathrm{CH}_{\mathrm{A}} \mathrm{H}_{\mathrm{B}} \mathrm{O}$ ], 3.68-3.72 (m, $\left.1 \mathrm{H}, \mathrm{H}-5\right)$, 3.44 [dt, $1 \mathrm{H}, J=9.6$ and $6.8 \mathrm{~Hz}, \mathrm{CH}_{3}\left(\mathrm{CH}_{2}\right)_{6} \mathrm{CH}_{\mathrm{A}} \mathrm{H}_{\mathrm{B}} \mathrm{O}$ ], 2.40 [t, $2 \mathrm{H}, J=7.6 \mathrm{~Hz}, \mathrm{CH}_{3}\left(\mathrm{CH}_{2}\right)_{2} \mathrm{CH}_{2} \mathrm{CO}$ ], 2.23-2.37 [m, 6H, $\mathrm{CH}_{3}\left(\mathrm{CH}_{2}\right)_{2} \mathrm{CH}_{2} \mathrm{CO}$ and $\left.2 \times \mathrm{CH}_{3}\left(\mathrm{CH}_{2}\right)_{5} \mathrm{CH}_{2} \mathrm{CO}\right], 1.46-1.66 \quad[\mathrm{~m}, \quad 10 \mathrm{H}$, $\mathrm{CH}_{3}\left(\mathrm{CH}_{2}\right)_{5} \mathrm{CH}_{2} \mathrm{CH}_{2} \mathrm{O}, 2 \times \mathrm{CH}_{3} \mathrm{CH}_{2} \mathrm{CH}_{2} \mathrm{CH}_{2} \mathrm{CO}$ and $2 \times \mathrm{CH}_{3}\left(\mathrm{CH}_{2}\right)_{4} \mathrm{CH}_{2} \mathrm{CH}_{2} \mathrm{CO}$ ], 1.18-1.38 [br m, $30 \mathrm{H}$, $\mathrm{CH}_{3}\left(\mathrm{CH}_{2}\right)_{5}\left(\mathrm{CH}_{2}\right)_{2} \mathrm{O}, \quad 2 \times \mathrm{CH}_{3} \mathrm{CH}_{2}\left(\mathrm{CH}_{2}\right)_{2} \mathrm{CO}$ and $\left.2 \times \mathrm{CH}_{3}\left(\mathrm{CH}_{2}\right)_{4}\left(\mathrm{CH}_{2}\right)_{2} \mathrm{CO}\right], \quad 0.88-0.96 \quad[\mathrm{~m}, \quad 15 \mathrm{H}$, $\mathrm{CH}_{3}\left(\mathrm{CH}_{2}\right)_{7} \mathrm{O}, 2 \times \mathrm{CH}_{3}\left(\mathrm{CH}_{2}\right)_{3} \mathrm{CO}$ and $\left.2 \times \mathrm{CH}_{3}\left(\mathrm{CH}_{2}\right)_{6} \mathrm{CO}\right]$.

\subsection{PASS predication}

Nowadays, several freely available computational programs are available online, which predict multi-target profiles of drug-like compounds [38]. Prediction of drug bio-profiles provides a nonlaborious and less expensive way for finding new human medicines. Computational assessment of bioactivity profiles shed light on the hidden pharmacological potential of the launched drugs. In this respect, we used web-based PASS (Prediction of Activity Spectra for Substances; http://www.way2drug.com/passonline/) for the prediction of a plethora of biological activities [39-41] which can predict or calculate a plethora of biological activities with $90 \%$ accuracy. The structures of the OBGs were drawn with ChemDraw 16.0, and then converted into their SD file format and used to calculate or predict biological spectrum using PASS online version (http://www.way2drug.com/passonline/). The calculated results are presented as $\mathrm{Pa}$ (probability for active compound) and $\mathrm{Pi}$ (probability for inactive compound). Here, $\mathrm{Pa}>\mathrm{Pi}$ is considered on the scale of 0.000 to 1.000 and in general, $\mathrm{Pa}+\mathrm{Pi} \neq 1$.

\subsection{Prediction of ADMET}

Pharmacokinetic (PK) properties such as ADMET (absorption, distribution, metabolism, excretion, and toxicity) analyses of the synthesized CFA esters were determined using the pkCSM ADMET descriptors algorithm protocol (http://biosig.unimelb.edu.au) [42]. This could avoid the tremendous cost and time associated with the in vivo experiments for drug discovery. First of all, appropriate OBG esters were converted to InChI Key, isomeric SMILES (simplified molecular-input line-entry system), and SD file formats. These formats were used to predict ADMET from online pkCSM-pharmacokinetics [43]. In addition, these data were compared with standard antibiotic (drug) fluconazole.

Nowadays, during the design of drug molecules, more attention is given to the molecules which fit into the rule of drug-likeness. For drug-likeness calculations, and medicinal chemistry friendliness,

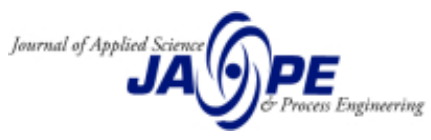


the same SMILES of the compounds were used. We employed SwissADME free web tools (http://www.swissadme.ch) to calculate various related parameters [44]. As one of the most important chemical descriptors which correlate well with PK properties, the topological polar surface area (TPSA) was calculated and explained with other drug-likeness parameters.

\section{Results and discussion}

\subsection{Synthesis of 3,6-di-O-pentanoate 5}

Octyl $\beta$-D-glucoside 4, a nonionic detergent, has been widely used for membrane protein solubilization. It is also useful for solubilizing enzymes, receptors, and phosphatidylcholine. It is nontoxic in cell lines, and inhibited the starch hydrolyzing enzyme $\alpha$-amylase to a good extent [45]. Furthermore, it was observed that the dimolar acylation of $\mathbf{4}$ in only pyridine solution gave 3,6-di- $O$ pentanoate in lower yield (56\%) [3]. To improve the yield, we conducted the reaction in different solvent systems. Even the use of DMAP catalyst also did not improve the yield. However, the use of a pyridine-chloroform (1:1) solvent system at $30^{\circ} \mathrm{C}$ was found to produce a comparatively higher yield. Accordingly, OBG 3 was treated with dimolar pentanoyl chloride in pyridine-chloroform solution for $10 \mathrm{~h}$ at $30^{\circ} \mathrm{C}$. Usual workup and purification gave a solid $\left(\mathrm{mp} 62-65^{\circ} \mathrm{C}\right)$ with a higher yield $(67 \%)$ (Scheme 1).
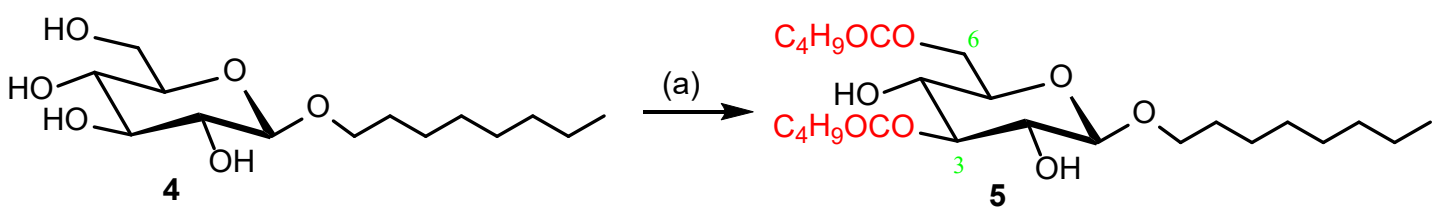

Scheme 1. Reagents and conditions: (a) Py-chloroform, $\mathrm{C}_{4} \mathrm{H}_{9} \mathrm{COCl}, 10-30{ }^{\circ} \mathrm{C}, 10 \mathrm{~h}, 67 \%$.

The presence of hydroxyl stretching at $3250-3540 \mathrm{~cm}^{-1}$ and characteristic carbonyl bands at 1741 and $1733 \mathrm{~cm}^{-1}$ indicated the partial pentanoylation of the molecule. The fact was further confirmed by analyzing its ${ }^{1} \mathrm{H}$ NMR spectrum, where two-proton broad singlet corresponding to two hydroxyl protons appeared at $\delta 1.21-1.28$. In addition to the glycosidic octyl group, extra eighteen protons appeared at the aliphatic region indicating the attachment of two pentanoyl groups in the molecule. The attachment of pentanoyl groups at C-3 and C-6 position was confirmed by the downfield shift of H-3 and H-6 protons compared to its precursor compound 4. Finally, its ${ }^{13} \mathrm{C}$ NMR spectrum showed two carbonyl signals at $\delta 174.4$ and 174.2, and thus, confirming the attachment of two pentanoyl groups in the molecule. Hence, the compound was assigned the structure as octyl 3,6di- $O$-pentanoyl- $\beta$-D-glucopyranoside (5). The formation of 3,6-di- $O$-pentanoate 5 clearly indicated that the reactivity order of hydroxyl groups in OBG 4 follows 6-OH, 3-OH $>2-\mathrm{OH}, 4-\mathrm{OH}$.

\subsection{Synthesis of 2,4-di-O-acyl esters 6-8}

Initially, pentanote 5 was treated with mesyl chloride at low temperature for $5 \mathrm{~h}$, which upon purification, gave an oil an $89 \%$ yield (Scheme 2). 


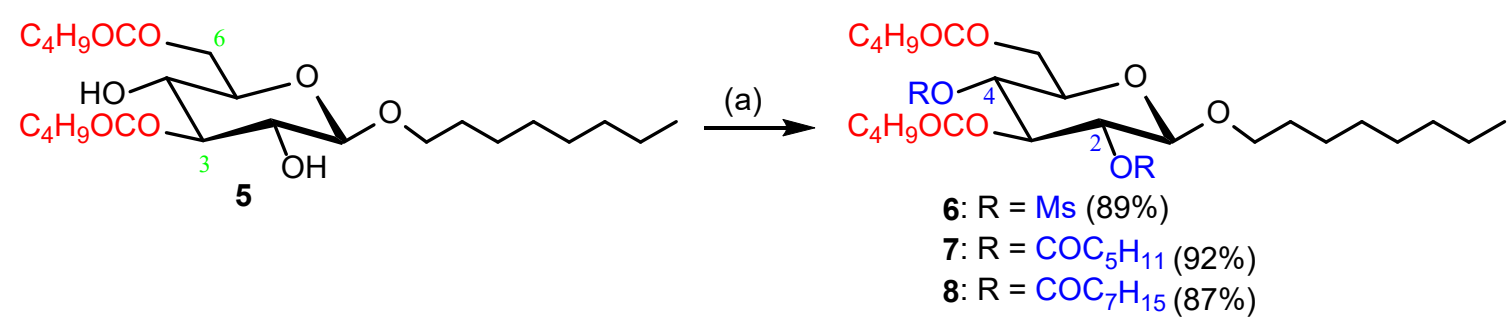

Scheme 2. Reagents and conditions: (a) dry $\mathrm{Py}, \mathrm{MsCl} / \mathrm{C}_{5} \mathrm{H}_{11} \mathrm{COCl} / \mathrm{C}_{7} \mathrm{H}_{15} \mathrm{COCl}, 0{ }^{\circ} \mathrm{C}-\mathrm{rt}, 5-12 \mathrm{~h}$.

Its FT-IR spectrum showed characteristic sulphonyl bands at 1365 and $1362 \mathrm{~cm}^{-1}$ in addition to two carbonyl bands. Also, the absence of hydroxyl stretching bands clearly demonstrated the mesylation of the molecule. In its ${ }^{1} \mathrm{H}$ NMR spectrum, two three-proton singlets at $\delta 3.29$ and $3.15 \mathrm{ppm}$ were assigned for the two mesyl $\left(\mathrm{CH}_{3} \mathrm{SO}_{2}-\right)$ groups. The spectrum indicated considerable downfield shift of $\mathrm{H}-2(\delta 4.99)$ and $\mathrm{H}-4(\delta 5.10)$ protons as compared to its precursor compound $\mathbf{5}(\delta 3.83-3.93$ and 3.46-3.59, respectively). These observations are in agreement with the attachment of mesyl groups at C-2 and C-4 positions. Complete analysis of the rest of the NMR spectrum led us to assign the structure of the compound as octyl 2,4-di-O-mesyl-3,6-di- $O$-pentanoyl- $\beta$-D-glucopyranoside (6).

In the next step, dimolar hexanoylation of 5 for $14 \mathrm{~h}$ followed by chromatography furnished a thick syrup in $92 \%$ yield (Scheme 2). Its FT-IR spectrum showed the absence of hydroxyl bands and exhibited four carbonyl bands at 1755, 1749, 1742 and $1738 \mathrm{~cm}^{-1}$ indicating the attachment of hexanoyl group in the molecule. In the ${ }^{1} \mathrm{H}$ NMR spectrum, glycosidic octyl group protons appeared in the aliphatic region. In addition, extra twenty-two protons appeared at $\delta 2.24-2.39,1.48-1.65,1.20$ $1.35,0.88-0.95$ along with the protons of two pentanoyl groups (which were already present at C-3 and $\mathrm{C}-6$ positions). Thus, in correlation with compound $\mathbf{6}$, the structure of the compound was assigned as octyl 2,4-di- $O$-hexanoyl-3,6-di- $O$-pentanoyl- $\beta$-D-glucopyranoside (7).

Finally, the reaction of $\mathbf{5}$ with octanoyl chloride in dry pyridine for $12 \mathrm{~h}$ followed by usual work-up and purification provided a semi-solid in good yield which resisted crystallization. Its FT-IR spectrum showed absence of hydroxyl band and shoed characteristic stretchings at 1754(2), 1742, $1738 \mathrm{~cm}^{-1}(\mathrm{CO})$. In its ${ }^{1} \mathrm{H}$ NMR spectrum, total of sixty-five protons resonated in the aliphatic region in addition to the glucopyanoside protons $(7 \mathrm{H})$. The appearance of extra thirty protons $(30 \mathrm{H})$ represented the incorporation of two octanoyl groups in the molecule. Also, H-2 and H-4 resonated considerable down fields. Based on spectral evidence the structure of the compound was unambiguously assigned as octyl 2,4-di- $O$-octanoyl-3,6-di- $O$-pentanoyl- $\beta$-D-glucopyranoside (8).

\subsection{PASS predicted biological activities}

In recent years, some freely available via the internet computational tools for the prediction of biological activity profiles of drug-like compounds have appeared and used to search for new targets which lead to new drugs. We used the prediction of activity spectra for substances (PASS) programme (http://www.way2drug.com/passonline/) for our synthesized compounds [38-41].

Having characterized CFA esters 5-8 in hand, their biological profile was predicted by PASS [38]. PASS biological results in its designated $\mathrm{Pa}$ and $\mathrm{Pi}$ form is presented in Table 1. 
Table 1. PASS predicted biological activities of the compound 4-8.

\begin{tabular}{|c|c|c|c|c|c|c|c|c|}
\hline \multirow{3}{*}{ Drug } & \multicolumn{8}{|c|}{ Biological activity } \\
\hline & \multicolumn{2}{|c|}{ Antibacterial } & \multicolumn{2}{|c|}{ Antifungal } & \multicolumn{2}{|c|}{ Anti-carcinogenic } & \multicolumn{2}{|c|}{ Antioxidant } \\
\hline & $\mathrm{Pa}$ & $\mathrm{Pi}$ & $\mathrm{Pa}$ & $\mathrm{Pi}$ & $\mathrm{Pa}$ & $\mathrm{Pi}$ & $\mathrm{Pa}$ & $\mathrm{Pi}$ \\
\hline 4 & 0.529 & 0.014 & 0.685 & 0.010 & 0.751 & 0.007 & 0.600 & 0.005 \\
\hline 5 & 0.563 & 0.011 & 0.738 & 0.008 & 0.798 & 0.005 & 0.560 & 0.005 \\
\hline 6 & 0.500 & 0.016 & 0.541 & 0.024 & 0.551 & 0.015 & 0.372 & 0.015 \\
\hline 7 & 0.544 & 0.013 & 0.705 & 0.009 & 0.646 & 0.011 & 0.508 & 0.006 \\
\hline 8 & 0.544 & 0.013 & 0.705 & 0.009 & 0.646 & 0.011 & 0.508 & 0.006 \\
\hline TTC & 0.694 & 0.005 & 0.523 & 0.023 & - & - & - & - \\
\hline FCZ & - & - & 0.726 & 0.008 & - & - & - & - \\
\hline
\end{tabular}

$\mathrm{Pa}=$ Probability 'to be active'; $\mathrm{Pi}=$ Probability 'to be inactive'; TTC = tetracycline; $\mathrm{FCZ}=$ fluconazole.

As shown in Table 1, PASS predication indicated that di-O-pentanoate 5 possess the highest antifungal activities $(\mathrm{Pa}=0.738)$ which is higher than that of the antifungal drug fluconazole $(\mathrm{Pa}=$ 0.726). Like other sugar-based mesyl esters [36], the addition of mesyl group(s), as in compound $\mathbf{6}$, decreased antifungal potentiality $(\mathrm{Pa}=0.541)$. While addition aliphatic ester group(s), as in $\mathbf{7}$ and $\mathbf{8}$, increased antifungal activities $(\mathrm{Pa}=0.705)$. Thus, esterification of $\mathrm{OBG}(4)$ with fatty acyl groups increased its antifungal potentiality than the sulphonyl ester. Similarly, esterification of OBG (3) with fatty acyl groups raised its antibacterial activity than the sulphonyl ester (6) although lower than the standard antibacterial drug tetracycline.

Notably, the addition of fatty acyl groups like pentanoyl increased the anti-carcinogenic properties of OBG (4). However, these CFA esters 5-8 have a lower antioxidant profile. In all respect, mesyl ester 6 showed a poor biological spectrum compared to aliphatic esters. Overall, the PASS predication indicated $0.50<\mathrm{Pa}<0.56$ for antibacterial and $0.54<\mathrm{Pa}<0.74$ for antifungal. Thus, the synthesized CFA esters 5-8 should be more potent against fungi than that of bacterial pathogens.

\subsection{ADMET properties}

Pharmacokinetic (PK) descriptors ADMET (absorption, distribution, metabolism, excretion, and toxicity) analyses of the synthesized compounds were determined using the pkCSM protocol (http://biosig.unimelb.edu.au) [42-43] and mentioned in Table 2. The absorption of drugs depends on factors including membrane permeability [indicated by colon cancer cell line (Caco-2)], human intestinal absorption (HIA), and P-glycoprotein substrate or inhibitor (P-gpI). Several CFA esters (7-8) were found $100 \%$ HIA which were better than that of the fluconazole $(87.82 \%)$. These compounds are not P-glycoprotein inhibitor. Their distribution as indicated by the blood-brain barrier (BBB), and central nervous system (CNS) permeability are also comparable to fluconazole. The CFA esters 5-8 including OBG (4) have better renal clearance concerning the standard drug. The prediction of toxicity, as indicated by the human ether-a-go-go-gene (hERG) inhibitor and oral rat acute toxicity $\left(\mathrm{LD}_{50}\right)$, indicated that these CFA esters are safe to use. 
Table 2. ADMET calculation of glucopyaranosides 4-8.

\begin{tabular}{|c|c|c|c|c|c|c|c|c|c|}
\hline \multirow{3}{*}{ Drug } & \multicolumn{2}{|c|}{ Absorption } & \multicolumn{3}{|c|}{ Distribution } & \multirow{3}{*}{$\begin{array}{c}\text { Metabolism } \\
\begin{array}{c}\text { CYP3A44 } \\
\text { substrate }\end{array}\end{array}$} & \multirow{3}{*}{$\begin{array}{c}\text { Excretion } \\
\text { Total } \\
\text { clearance }\end{array}$} & \multirow{3}{*}{$\begin{array}{c}\text { Toxicity } \\
\text { hERG } \\
\text { inhibitor }\end{array}$} & \multirow{3}{*}{$\begin{array}{l}\mathrm{LD}_{50} \\
\text { (rat) }\end{array}$} \\
\hline & \multirow[t]{2}{*}{$\mathrm{C} 2 \mathrm{P}$} & \multirow{2}{*}{$\begin{array}{l}\text { HIA } \\
(\%)\end{array}$} & \multirow{2}{*}{$\begin{array}{l}\text { P- } \\
\text { gpI }\end{array}$} & \multirow{2}{*}{\multicolumn{2}{|c|}{$\begin{array}{l}\text { BBB CNS } \\
\text { (permeability) }\end{array}$}} & & & & \\
\hline & & & & & & & & & \\
\hline 4 & -0.191 & 39.392 & No & -1.212 & -3.431 & No & 1.671 & No & 2.18 \\
\hline 5 & 0.803 & 74.46 & Yes & -0.929 & -0.929 & Yes & 1.879 & No & 2.527 \\
\hline 6 & -0.229 & 100 & Yes & -2.623 & -3.741 & Yes & 1.468 & No & 2.041 \\
\hline 7 & 0.818 & 100 & Yes & -1.979 & -2.794 & Yes & 1.774 & No & 1.758 \\
\hline 8 & 0.776 & 100 & Yes & -2.067 & -2.688 & Yes & 1.845 & No & 2.113 \\
\hline FZ & 1.191 & 87.82 & No & -1.200 & -3.221 & No & 0.386 & No & 2.21 \\
\hline
\end{tabular}

$\mathrm{C} 2 \mathrm{P}=$ Caco-2 permeability ( $\log$ Papp in $10^{-6} \mathrm{~cm} / \mathrm{s},>0.90$ indicates high permeability); HIA = Human intestinal absorption (\% absorbed, $>30 \%$ is better absorbed); P-gpI = P-glycoprotein inhibitor; BBB (blood brain barrier) is expressed in $\log \mathrm{BB}(\log \mathrm{BB}>-1.0$ is moderately cross blood brain barrier); CNS is expressed as $\log \mathrm{PS}(\log \mathrm{PS}>-2.0$ can easily penetrate the CNS); Total clearance is expressed in $\log \mathrm{mL} / \mathrm{min} / \mathrm{kg}$; Toxicity is calculated in oral rat acute toxicity $(\mathrm{mol} / \mathrm{kg}) ; \mathrm{FZ}=$ fluconazole.

Drug-likeness calculation was conducted by the SwissADME program [44] and summarized in Table 3. According to the Lipinski rule, one of the most important chemical descriptors that correlate well with PK properties is the topological polar surface area (TPSA), and the TPSA of a good drug should be less than $140 \AA^{2}$. In the present study, all the CFA esters (except sulphonyl ester 6) have TPSA less than $124 \AA^{2}$ (Figure 3) and this satisfies the Lipinski rule. Metabolism is predicted based on the CYP models for substrate or inhibition (CYP1A2, CYP2C19, CYP2C9, CYP2D6, and CYP3A4) indicated an acceptable range (Table 3). Pan-assay interference compounds (PAINS) are chemical compounds that often give false-positive results in high-throughput screens. It is clear from Table 3 that these synthesized compounds have not violated PAINS. Also, the CFA esters do not have any toxic functional group(s). Based on both ADME and SwissADME along with PASS results, it can be expected that the OBG based CFA esters, especially $\mathbf{7}$ and $\mathbf{8}$, could be better dug candidates. Encouraged by these results in vivo and in vitro ADMET related other applied studies will be conducted for further confirmation of such compounds [45-49].

Table 3. Calculation of drug-likeness using SwissADME descriptors.

\begin{tabular}{cccccccccc}
\hline Drug & $\begin{array}{c}\text { HB } \\
\text { acceptors }\end{array}$ & $\begin{array}{c}\text { HB } \\
\text { donors }\end{array}$ & $\begin{array}{c}\text { TPSA } \\
\AA^{2}\end{array}$ & $\begin{array}{c}\text { CYP1A2 } \\
\text { inhibitor }\end{array}$ & $\begin{array}{c}\text { CYP2C19 } \\
\text { inhibitor }\end{array}$ & $\begin{array}{c}\text { CYP2C9 } \\
\text { inhibitor }\end{array}$ & $\begin{array}{c}\text { CYP2D6 } \\
\text { inhibitor }\end{array}$ & $\begin{array}{c}\text { CYP3A4 } \\
\text { inhibitor }\end{array}$ & $\begin{array}{c}\text { PAINS } \\
\text { alerts }\end{array}$ \\
\hline $\mathbf{4}$ & 6 & 4 & 99.38 & No & No & No & No & No & 0 \\
$\mathbf{5}$ & 8 & 2 & 111.52 & No & Yes & No & No & Yes & 0 \\
$\mathbf{6}$ & 12 & 0 & 174.56 & No & Yes & No & No & No & 0 \\
$\mathbf{7}$ & 10 & 0 & 123.66 & No & No & No & No & No & 0 \\
$\mathbf{8}$ & 10 & 0 & 123.66 & No & No & No & No & No & 0 \\
\hline
\end{tabular}

$* \mathrm{HB}=$ Hydrogen bond, TPSA $=$ Topological polar surface area, PAINS = Pan-assay interference compounds 


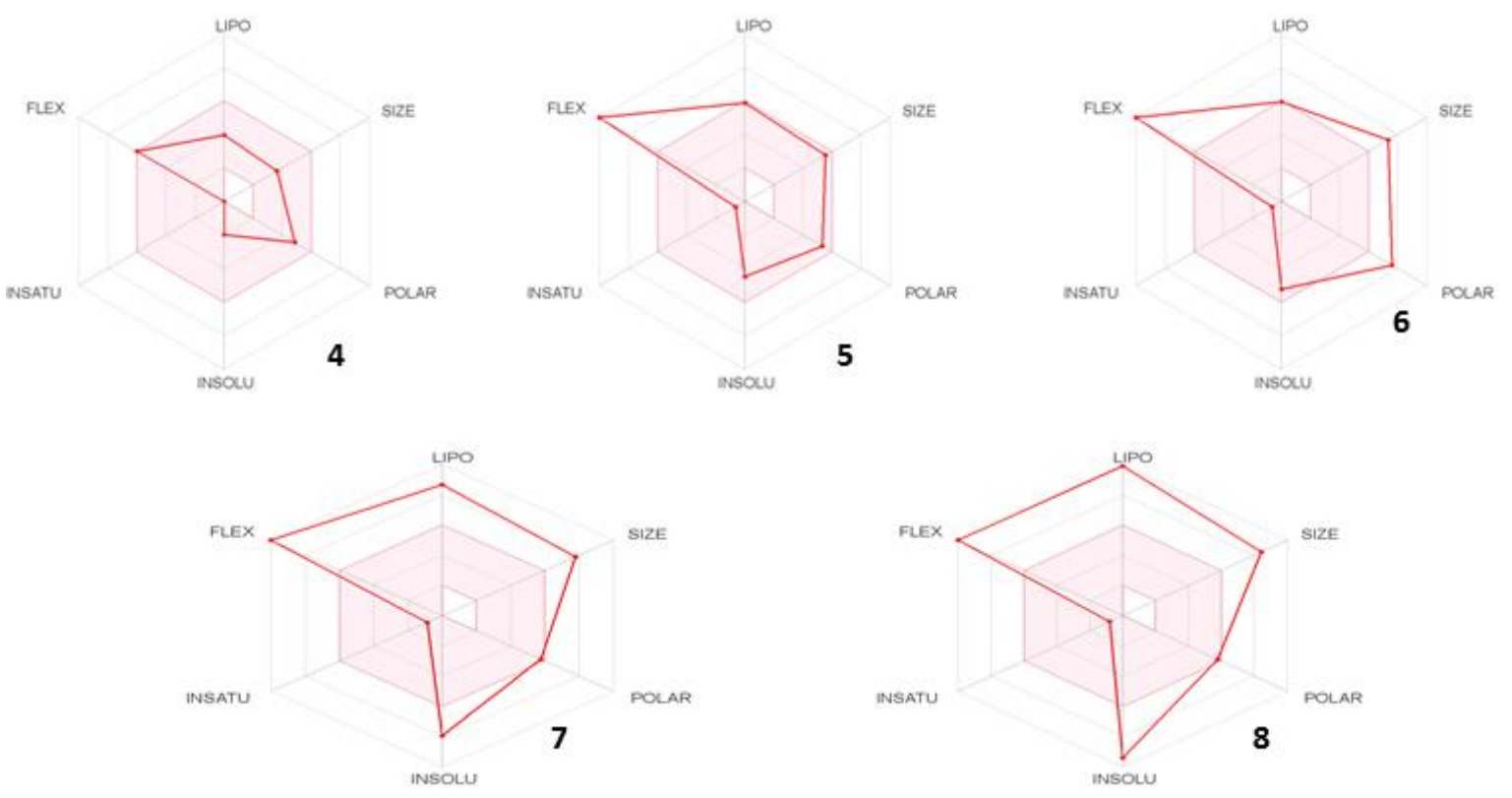

Figure 3. Topological polar surface area (TPSA) of glucopyranoside 4-8.

\section{Conclusion}

An efficient method for di- $O$-pentanoylation of octyl $\beta$-D-glucopyranoside (4) with improved yield is discussed. Easy reaction conditions and convenient work-up procedure will make the technique favourable for further application in other sugars. For structural elucidation as well as to get newer CFA esters, dipentanoate 5 was further converted into three 2,4-di- $O$-acylates 6-8 in good yields. All the CFA esters (5-8) were characterized well by spectroscopic techniques. PASS predication profile indicated that esterification of OBG (4) with fatty acyl groups increased its antifungal potentiality more than the sulphonyl ester. Pharmacokinetic (PK) descriptors ADMET showed safer nature of these CFA esters concerning human intestinal absorption (HIA), human ethera-go-go-gene $(\mathrm{hERG})$ inhibition and rat acute oral toxicity $\left(\mathrm{LD}_{50}\right)$. Also, drug-likeness calculation as conducted by the SwissADME programme was in support of the ADMET and PASS predication results. Especially, the CFA esters topological polar surface area (TPSA) was found below $124 \AA^{2}$. Based on these encouraging results, further biological studies are in progress to establish them as potential antifungal agents.

\section{Acknowledgements}

We highly acknowledge the financial support from the Research and Publication Cell, University of Chittagong, Bangladesh (2020-2021).

\section{References}

[1] Zheng, Y., Zheng, M., Ma, Z., Xin, B., Guo, R., \& Xu, X. (2015). Sugar Fatty Acid Esters. In Polar Lipids: Biology, Chemistry, and Technology, pp 215-243, Elsevier B.V. https://doi.org/10.1016/B978-1-63067044-3.50012-1

[2] Abd-Elbary, A., El-Laithy, H. M., \& Tadros, M. I. (2008). Sucrose stearate-based proniosome-derived niosomes for the nebulisable delivery of cromolyn sodium, International Journal of Pharmacy, Vol.357, 189-198. https://doi.org/10.1016/j.ijpharm.2008.01.056 
[3] Matin, M. M., Chakraborty, P., Alam, M. S., Islam, M. M., \& Hanee, U. (2020). Novel mannopyranoside esters as sterol 14 $\alpha$-demethylase inhibitors: Synthesis, PASS predication, molecular docking, and pharmacokinetic studies, Carbohydrate Research, Vol.496, 108130. https://doi.org/10.1016/j.carres.2020.108130

[4] Matin, M. M., Bhuiyan, M. M. H., Kabir, E., Sanaullah, A. F. M., Rahman, M. A., Hossain, M. E., \& Uzzaman, M. (2019). Synthesis, characterization, ADMET, PASS predication, and antimicrobial study of 6-O-lauroyl mannopyranosides, Journal of Molecular Structure, Vol.1195, 189-197. https://doi.org/10.1016/j.molstruc.2019.05.102

[5] Kabir, A. K. M. S., \& Matin, M. M. (1998). Synthesis and characterization of some D-mannose derivatives, The Chittagong University Journal of Science, Vol.22, No.1, 105-110. ISSN: 1561-1167

[6] Matin, M. M., Hasan, M. S., Uzzaman, M., Bhuiyan, M. M. H., Kibria, S. M., Hossain, M. E., \& Roshid, M. H. O. (2020). Synthesis, spectroscopic characterization, molecular docking, and ADMET studies of mannopyranoside esters as antimicrobial agents, Journal of Molecular Structure, Vol.1222, 128821. https://doi.org/10.1016/j.molstruc.2020.128821

[7] Chansanroj, K., \& Betz, G. (2010). Sucrose esters with various hydrophilic-lipophilic properties: Novel controlled release agents for oral drug delivery matrix tablets prepared by direct compaction, Acta Biomaterialia, Vol.6, 3101-3109. https://doi.org/10.1016/j.actbio.2010.01.044

[8] Matin, M. M., Ibrahim, M., \& Rahman, M. S. (2008). Antimicrobial evaluation of methyl 4-O-acetyl- $\alpha$-Lrhamnopyranoside derivatives, The Chittagong University Journal of Biological Sciences, Vol.3, No.1\&2, 33-43. http://dx.doi.org/10.3329/cujbs.v3i1.13404

[9] Matin, M. M., Bhattacharjee, S. C., Chakraborty, P., \& Alam, M. S. (2019). Synthesis, PASS predication, in vitro antimicrobial evaluation and pharmacokinetic study of novel $n$-octyl glucopyranoside esters, Carbohydrate Research, Vol.485, 107812. https://doi.org/10.1016/j.carres.2019.107812

[10] Matin, M. M., Uzzaman, M., Chowdhury, S. A., \& Bhuiyan, M. M. H. (2020). In vitro antimicrobial, physicochemical, pharmacokinetics, and molecular docking studies of benzoyl uridine esters against SARS-CoV-2 main protease, Journal of Biomolecular Structure and Dynamics. https://doi.org/10.1080/07391102.2020.1850358

[11] Matin, M. M. (2008). Synthesis of D-glucose derived oxetane: 1,2-O-isopropylidene-4-(S)-3-O,4-Cmethylene-5-O-methanesulfonyl- $\alpha$-L-threo-pento-1,4-furanose, Journal of Applied Sciences Research, Vo.4, No.11, 1478-1482. ISSN: 1816157X

[12] Dhavale, D. D., \& Matin, M. M. (2004). Selective sulfonylation of 4- $C$-hydroxymethyl- $\beta$-L-threo-pento1,4-furanose: Synthesis of bicyclic diazasugars, Tetrahedron, Vol.60, No.19, 4275-4281. https://doi.org/10.1016/j.tet.2004.03.034

[13] Matin, M. M. (2008). One step intramolecular cyclization of diol via mesylation: Efficient synthesis of sugar derived [1,4]oxazepanes, Journal of Bangladesh Chemical Society, Vol.21, No.2, 179-183. ISSN 1022-016X

[14] Yuan, S. S., Li, M. L., Chen, J. S., Zhou, L., \& Zhou, W. (2017). Application of mono- or disaccharides in drug targeting and efficacy, ChemMedChem, e 10.1002/cmdc.201700762. https://doi.org/10.1002/cmdc.201700762

[15] Matin, M. M. (2004). Synthesis and study of glycosidase inhibitory activity of piperidine, pyrrolidine and bicyclic azasugars, $P h D$ Thesis, University of Pune, India.

[16] AlFindee, M.N., Zhang, Q., Subedi, Y. P., Shrestha, J. P., Kawasaki, Y., Grilley, M., Taemoto, J. Y., \& Chang, C. W. T. (2018). One-step synthesis of carbohydrate esters as antibacterial and antifungal agents, Bioorganic and Medicinal Chemistry, Vol.26, 765-774. https://doi.org/10.1016/j.bmc.2017.12.038

[17] Tolnia, G. L., Nilsson, U. J., \& Olofsson, B. (2016). Efficient $O$-functionalization of carbohydrates with electrophilic reagents, Angewandte Chemie International, Edition, Vol.55, 11226-11230. https://doi.org/10.1002/anie.201605999 
[18] Matin, M. M., Bhuiyan, M. M. H., Azad, A. K. M. S., \& Akther, N. (2017). Design and synthesis of benzyl 4-O-lauroyl- $\alpha$-L-rhamnopyranoside derivatives as antimicrobial agents, Current Chemistry Letters, Vol.6, No.1, 31-40. https://doi.org/10.5267/j.ccl.2016.10.001

[19] Matin, M. M., Bhuiyan, M. M. H., Azad, A. K. M. S., \& Rashid, M. H. O. (2015). Synthesis of 6-Ostearoyl-1,2- $O$-isopropylidene- $\alpha$-D-gluco-furanose derivatives for antimicrobial evaluation, Journal of Physical Science, Vo.26, No.1, 1-12. ISSN: 2180-4230

[20] Kabir, A. K. M. S., \& Matin, M. M. (1994). Regioselective acylation of a derivative of L-rhamonse using the dibutyltin oxide method, Journal of the Bangladesh Chemical Society, Vol.7, No.1, 73-79. ISSN: 1022$016 \mathrm{X}$

[21] Kabir, A. K. M. S., \& Matin, M. M. (1997). Regioselective monoacylation of a derivative of L-rhamnose, Journal of Bangladesh Academy of Sciences, Vol.21, No.1, 83-88. ISSN 0378-8121

[22] Kiyoshima, K., Sakamoto, M., Ishikura, T., Fukagawa, Y., Yoshioka, T., Naganawa, H., Sawa, T., \& Takeuchi, T. (1989). Application of dibutyltin oxide method to regioselective acylation and alkylation of tylosin at C-4", Chemical and Pharmaceutical Bulletin, Vo.37, No.4, 861-865. https://doi.org/10.1248/cpb.37.861

[23] Kabir, A. K. M. S., Matin, M. M., Bhuiyan, M. M. R., \& Rahim, M. A. (2001). Synthesis and characterization of some acylated derivatives of D-mannose, The Chittagong University Journal of Science, Vo.25, No.1, 65-73. ISSN: 1561-1167

[24] Kabir, A. K. M. S., Matin, M. M., Kawsar, S. M. A., \& Anwar, M. N. (1998). Antibacterial activities of some selectively acylated uridine derivatives, The Chittagong University Journal of Science, Vol.22, No.2, 37-41. ISSN: 1561-1167

[25] Matin, M. M., \& M. Ibrahim (2010). Synthesis of some methyl 4-O-octanoyl- $\alpha$-L-rhamnopyranoside derivatives, Journal of Applied Sciences Research, Vol.6, No.10, 1527-1532. ISSN: 1816-157X

[26] Gumel, A. M., Annuar, M. S. M., Heidelberg, T., \& Chisti, Y. (2011). Lipase Mediated synthesis of Sugar fatty acid esters, Process Biochemistry, Vol.46, 2079-2090. https://doi.org/10.1016/j.procbio.2011.07.021

[27] Ortiz, Á. D-., Prieto, P., \& de la Hoz, A. (2019). A critical overview on the effect of microwave irradiation in organic synthesis, The Chemical Record, Vol.19, No.1, 85-97. https://doi.org/10.1002/tcr.201800059

[28] Kabir, A. K. M. S., Matin, M. M., \& Uddin, M. R. (1998). Comparative studies on selective acylation of uridine using the dibutyltin oxide and direct methods, The Chittagong University Journal of Science, Vol.22, No.1, 97-103. ISSN: 1561-1167

[29] Ren, D. B., Zhang, L., \& Zhang, M. (2019). Progress on selective acylation of carbohydrate hydroxyl groups, Asian Journal of Organic Chemistry, Vol.8, 1813-1823. https://doi.org/10.1002/ajoc.201900400

[30] Matin, M. M. (2006). Synthesis of some protected 6-O-acyl-galactopyranose derivatives for antibacterial evaluation, The Chittagong University Journal of Science, Vol.30, No.2, 59-65. ISSN: 1561-1167

[31] Abronina, P. I., Malysheva, N. N., Zinin, A. I., Kolotyrkina, N. G., Stepanova, E. V., \& Kononov, L. O. (2020). Catalyst-free regioselective acetylation of primary hydroxy groups in partially protected and unprotected thioglycosides with acetic acid, RSC Advances, Vol.10, 36836-36842. https://doi.org/10.1039/D0RA07360A

[32] Matin, M. M., \& Azad, A. K. M. S. (2006). Synthesis of some protected 6-O-acyl-galactopyranose derivatives, Journal of Applied Sciences Research, Vol.2, No.12, 1199-1202. ISSN: 1816157X

[33] Matin, M. M., Bhuiyan, M. M. H., Hossain, M. M., \& Roshid, M. H. O. (2015). Synthesis and comparative antibacterial studies of some benzylidene monosaccharide benzoates, Journal of the Turkish Chemical Society Section A: Chemistry, Vol.2, No.4, 12-21. https://doi.org/10.18596/jotcsa.83708

[34] Kabir, A. K. M. S., \& Matin, M. M. (1999). Antibacterial activities of some monosaccharide derivatives, The Chittagong University Journal of Science, Vol.23, No.2, 121-123. ISSN: 1561-1167

[35] Kabir, A. K. M. S., Matin, M. M., \& Bhuiyan, M. J. U. (1997). Regioselective monoacylation of methyl 4,6-O-benzylidene- $\alpha$-D-glucopyranoside, Chittagong University Studies, Part II: Science, Vol.21, No.2, 33 38. ISSN: 1561-1167 
[36] Matin, M. M., \& Chakraborty, P. (2020). Synthesis, spectral and DFT characterization, PASS predication, antimicrobial, and ADMET studies of some novel mannopyranoside esters, Journal of Applied Science \& Process Engineering, Vol.7, No.2, 572-586. https://doi.org/10.33736/jaspe.2603.2020

[37] Matin, M. M., Chowdhury, S. A., Bhuiyan, M. M. H., Kawsar, S. M. A., \& Alam, M. A. (2021). Glucopyranoside dipentanoyl esters: Synthesis, PASS predication, antimicrobial and in silico ADMET studies, Journal of Scientific Research, Vol.13, No.1, 221-235. http://dx.doi.org/10.3329/jsr.v13i1.48147

[38] Murtazalieva, K. A., Druzhilovskiy, D. S., Goel, R. K., Sastry, G. N., \& Poroikov, V. V. (2017). How good are publicly available web services that predict bioactivity profiles for drug repurposing?, SAR and QSAR in Environmental Research, Vol.28, No.10, 843-862. https://doi.org/10.1080/1062936X.2017.1399448

[39] Matin, M. M., Nath, A. R., Saad, O., Bhuiyan, M. M. H., Kadir, F. A., Hamid, S. B. A., Alhadi, A. A., Ali, M. E., \& Yehye, W.A. (2016). Synthesis, PASS-predication and in vitro antimicrobial activity of benzyl 4O-benzoyl- $\alpha$-L-rhamnopyranoside derivatives, International Journal of Molecular Sciences, Vol.17, No.9, 1412. https://doi.org/10.3390/ijms 17091412

[40] Chowdhury, S. A., Chakraborty, P., Kawsar, S. M. A., Bhuiyan, M. M. H., Matin, M. M. (2018). Regioselective acylation, PASS prediction and antimicrobial properties of some protected glucopyranosides, Journal of Bangladesh Chemical Society, Vol.30, No.1, 1-9. ISSN 1022-016X

[41] Matin, M. M., Roshid, M. H. O., Bhattacharjee, S. C., \& Azad, A. K. M. S. (2020). PASS predication, antiviral, in vitro antimicrobial, and ADMET studies of rhamnopyranoside esters, Medical Research Archives, Vol.8, No.7, 2165. https://doi.org/10.18103/mra.v8i7.2165

[42] Han, Y., Zhang, J., Hu, C. Q., Zhang, X., Ma, B., \& Zhang, P. (2019). In silico ADME and toxicity prediction of Ceftazidime and its impurities, Frontiers Pharmacology, Vol.10, 434. https://doi.org/10.3389/fphar.2019.00434

[43] Rahim, A., Bhuiyan, M. M. H., \& Matin, M. M. (2020). Microwave assisted efficient synthesis of some flavones for antimicrobial and ADMET studies, Journal of Scientific Research, Vol.12, No.4, 673-685. http://dx.doi.org/10.3329/jsr.v12i4.45523

[44] Lohidakshan, K., Rajan, M., Ganesh, A., Paul, M., Jerin, J. (2018). Pass and Swiss ADME collaborated in silico docking approach to the synthesis of certain pyrazoline spacer compounds for dihydrofolate reductase inhibition and antimalarial activity, Bangladesh Journal of Pharmacology, Vol.13, 23-29. eISSN: 1991-0088

[45] Dinesh, M., Deepika, S., Kumar, R. H., Selvaraj, C. I., \& Roopan, S. M. (2017). Evaluation of octyl- $\beta$-Dglucopyranoside (OGP) for cytotoxic, hemolytic, thrombolytic, and antibacterial activity, Applied Biochemistry and Biotechnologr, Vol.185, No.4, 450-463. https://doi.org/10.1007/s12010-017-2661-7

[46] Kabir, A. K. M. S., \& Matin, M. M. (1996). Selective pivaloylation of some D-glucose derivatives, Chittagong University Studies, Part II: Science, Vol.20, No.2, 105-111. ISSN: 1561-1167

[47] Matin, M. M. (2014). Synthesis and antimicrobial study of some methyl 4-O-palmitoyl- $\alpha$-Lrhamnopyranoside derivatives, Orbital: The Electronic Journal of Chemistry, Vol.6, No.1, 20-28. https://doi.org/10.17807/orbital.v6i1.553

[48] Kabir, A. K. M. S., Matin, M. M., Bhuiyan, M. M. R., Rahim, M. A., \& Rahman, M. S. (2005). Biological evaluation of some monosaccharide derivatives International Journal of Agriculture and Biology, Vol.7, No.2, 218-221. ISSN 1814-9596

[49] Matin, M. M., Bhuiyan, M. H., Hossain, M. M., \& Roshid, M. H. O. (2015). Comparative antibacterial activities of some monosaccharide and disaccharide benzoates, Orbital: The Electronic Journal of Chemistry, Vol.7, No.2, 160-167. https://doi.org/10.17807/orbital.v7i2.699 